\title{
A Comprehensive Study of the Prevalent Personal Values: Investigating Working Generation Y'ers in Turkey
}

\author{
İpek Altınbaşak-Farina* \\ Bahçeşehir University
}

\author{
Gözde Güleryüz-Türkel** \\ Bahçeşehir University
}

\begin{abstract}
The main aim of the study is to investigate the prevalent personal values of working Generation Y'ers in Turkey. With this objective, the Schwartz Values Survey has been adapted and a new values scale specific to Generation Y'ers is developed. Furthermore, the relationships of those prevalent personal values with other variables such as the level of religious commitment and gender are investigated. Data collected from 361 respondents reveal that "independence" (freedom, justice, self-respect, privacy) and "trust" (sincerity, honesty, true friendship) value dimensions are rated as the most important. The "tradition" (obedience, devotion, honoring the elders) value dimension which is rated as the least important is found to be highly associated with religious commitment. Taking into consideration the size, purchasing power and business status of Gen Y'ers, the study is expected to provide implications for businesses and social scientists especially from the marketing, management, psychology and sociology fields.

Keywords: Gen Y, generational cohort, Millennials, religious commitment, values, personal values, global marketing, marketing management, psychology, sociology.
\end{abstract}

\section{Yaygın Kişisel Değerlerle İlgili Kapsamlı Bir Calışma: Türkiye’de Çalışan Y Jenerasyonu Üzerinde İnceleme}

\section{Özet}

Bu çalışmanın temel amacı Türkiye'de iş hayatına atılmış Y kuşağının yaygın kişisel değerlerini ortaya koymaktır. Schwartz Değerler Araştırması adapte edilerek, Y kuşağ1 özelinde yeni bir ölçek oluşturulmuştur. Ayrıca, Y kuşağının yaygın değerlerinin dinsel bağlılık ve cinsiyet gibi farklı değişkenlerle ilişkisi incelenmiştir. 361 katılımcıdan elde edilen sonuçlar "bağımsızlık" (özgürlük, adalet, öz-sayg1, özel hayata sayg1) ve "güven" (samimiyet, dürüstlük, gerçek arkadaşlık) ana değer boyutlarının en yüksek düzeyde önemli bulunduğunu ortaya koymaktadır. Ayrıca, dine bağlılık ile en fazla ilişkili görülen "geleneksellik" (itaatkarlık, dindarlık, büyüklere saygı), çalışan Y kuşağının en

* İpek Altınbaşak-Farina is a Professor in the Department of Business Administration at Bahçeşehir University, Çırağan Caddesi, Osmanpaşa Mektebi Sokak, 4-6, 34349, Beşiktaş, Istanbul, Turkey. E-mail: ipek.altinbasak@hotmail.com

** Gözde Güleryüz-Türkel is a PhD. Candidate in the Institute of Social Sciences at Bahçeşehir University, Çrrağan Caddesi, Osmanpaşa Mektebi Sokak, 4-6, 34349, Beşiktaş, Istanbul, Turkey. E-mail: guleryuzgzd@gmail.com 
az önem verdiği değer boyutu olarak saptanmıştır. Y kuşağının büyüklügüu, alım gücü ve iş dünyasındaki artan gücü dikkate alındığında, çalışmanın iş dünyası, ve özellikle pazarlama, yönetim, psikoloji ve sosyoloji gibi alanlardaki sosyal bilimciler açısından önemli bulgular ortaya koyduğu düşünülmektedir.

Anahtar Kelimeler: Y Jenerasyonu, Y Kuşağl, global pazarlama, pazarlama, yönetim, psikoloji, sosyoloji, millennials, dinsel bağlllık, değerler.

$\mathrm{T}$ The study mainly aims to discover the values of young managers belonging to Gen Y in Turkey. With this purpose Schwartz's list of values has been adapted and tested so that a new scale specific to Gen Y has been created. Taking into consideration that the subject has not been investigated in countries with prevalently Muslim populations, another aim of the study is to investigate the relationship between values and religious commitment. Values have been taking the attention of researchers from different fields (Ajzen, 1991; Feather, 1995; Kahle 1983; Rokeach, 1973; Schwartz, 1992, 1994, 2012; and Seligman and Katz, 1996). Understanding the value systems of individuals is crucial especially for academics in the social sciences and for business practitioners in order to predict consumer behavior and develop strategies accordingly. The impact of personal and cultural values on managers' moral behavior has been widely investigated as well (Akaah and Lund, 1994; England, 1967; and Posner and Schmidt, 1993). The link between ethical decision making and personal values is another topic of interest (Barnett Karson, 1987; Fritzsche, 1995; and Fritzsche and Oz, 2007). However, it is also observed that values are culture and generation specific (Schwartz and Rubel, 2005; and Schwartz and Sagiv, 1995). Therefore, cross-cultural research is expected to improve the knowledge about the value systems of different cultural groups. Furthermore, research specific to a certain generation will highlight the characteristics of this generation cohort and will make comparisons with others possible.

Another subject that generates attention has been the relationship between values and religiosity. Although theorists' findings may differ in terms of the specific values they link to religion, almost all agree that there is a relationship between the values and religious commitment of an individual (Brown, 1988; Wulff,1991). Schwartz and Huismans (1995) state that the value priorities are highly correlated to individuals' commitment to the religion they profess, since religions provide occasions or constitute obstacles to the achievement of valued goals.

Taking into consideration the size and consumption power of Gen $\mathrm{Y}$, this cohort is forming an important group to be analyzed by marketers, other social scientists and business practitioners in order to understand their perception of life, and to create strategies to appeal to them as internal and external customers. Therefore, this study aims firstly to examine the values of Gen Y'ers in Turkey through the creation of a scale specific to that generation. With the assumption that the values may tend to mature after the encounter with business life, Gen Y members who are currently university students are not included in the sample, but working Gen Y'ers are chosen as the unit to be focused 
on. Furthermore, the relationship between the values and religious commitment of this generation cohort is investigated in a secular country where $99.2 \%$ of its citizens are Muslim (Turkish Presidency of Religious Affairs, July 2015). Although there is abundant research on the topic in Western countries where Christianity is prevalent, Turkey is expected to present an interesting case to study religiosity and values.

The study includes a literature review on values, relationship between values and religious commitment, and Gen Y. This section is followed by hypothesis development and the methodology of the empirical study. In the last section, the findings are discussed in order to highlight the theoretical and managerial implications of the study, and to provide the limitations and suggestions for further research.

\section{Conceptual Framework: Values, Religious Commitment, and Generation Y}

The literature review presented in this section will present previous research on the three main topics of interest of the article: (1) values, (2) relationship between values and religious commitment, and (3) Generation Y.; it will lay the ground for the empirical study. The main studies related to these three topics have been investigated and presented to show different results obtained by different researchers in different cultures.

\section{Value Research}

"Values are both a powerful explanation of and influence on human behavior (Kahle, 1983; Rokeach, 1973)." Schwartz (1994) defined values as "desirable, transsituational goals" that serve "as a guiding principle in peoples" lives. Seligman and Katz (1996) stated that values reflect beliefs in the desirability of a certain end-state and therefore function as general predictors for attitudes, intentions and behavior. Values are predictors in almost all behavioral contexts (Ajzen, 1991). The concept is argued to be fundamental for the marketing discipline since values influence the consumers' purchasing behavior, goals and ideals (Rintamäki et al., 2007). According to Feather (1995), values are relatively stable over time, whereas behavior-specific beliefs and attitudes can change more easily.

Research regarding personal values has been enduring for many years within social psychology (Kahle, 1983, Rokeach; 1973; and Schwartz, 1992). Rokeach defined value and developed a comprehensive list of values, namely the "Rokeach Value Survey." Kahle (1983) developed the List of Values (LOV) which has three dimensions and nine items in total. These three dimensions are 1. external values (being well respected, security and sense of belonging); 2. internal values (value items: sense of accomplishment, self-fulfillment, warm relationships with others and self-respect); and 3. interpersonal values (fun and enjoyment in life and excitement). Schwartz (1992) comes up with a value survey with ten motivational value types covering fifty-six items. He dropped one item and added two others in 1994 (Schwartz, 2012). These ten motivational value types and fifty-seven items are all summarized in Table 1. Spini (2003) also came up 
with a similar classification in her study about Schwartz's value items. Schwartz and Bilsky (1987) were the first researchers who hypothesized and tested both the "Rokeach Value Survey" and the "Schwartz Value Survey" in cross-cultural situations. SVS has been widely used to demonstrate the impact of personal values on ethical behavior such as attitudes toward corporate social responsibility (Ramasamy et al., 2010; Shafer et al.,2007;), fair trade consumption (Doran, 2009), ethical managerial decision making (Lu et al. 1999; Fritzsche and Oz, 2007) and ethical consumer decision making (Shaw et al., 2005). In this article, SVS has been adapted to working Gen Y'ers in Turkey.

Ralston et al. (2011), adopted SVS to find out the value priorities of business managers and professionals across fifty societies. In the context of the study, 124 Turkish professionals, of which $70 \%$ were men with an average age of forty, have been included in the study. According to the findings, the values related to the "Tradition dimension" proved to have the least importance, whereas "Security dimension" appeared to be the most valuable one for the Turkish professionals.

Another noteworthy study regarding the values of the Turkish population was a World Value Survey adopted by Esmer in 2012. The results of this survey put forward interesting findings about the values of Turkish population. There are some issues that differentiate the Turkish population from that of Europe. For instance, Turkish people have a lack of trust in general, and their family is the institution they trust the most. On the other hand, they are found to be one of the most religious countries in Europe and even in the world. According to the report, the level of religiosity, in other words commitment to religion, decreases as the level of education increases.

\section{Table 1}

\section{Motivational Types of Values in Terms of Their Goals and Value Items}

\footnotetext{
POWER: Social status and prestige, control or dominance over people and resources. (Authority. Wealth. Social power. Preserving my public image. Social recognition) (5)

ACHIEVEMENT: Personal success through demonstrating competence according to social standards. (Ambitious. Successful. Capable. Influential. Intelligent. Self-respect) (6)

HEDONISM: Pleasure and sensuous gratification for oneself. (Pleasure. Enjoying Life. Self-indulgent) (3)

STIMULATION: Excitement, novelty, and challenge in life. (Daring, a Varied Life, an Exciting Life) (3)

SELF-DIRECTION: Independent thought and action-choosing, creating, exploring. (Creativity. Freedom. Independent. Curious. Choosing Own Goals. Privacy) (6)

UNIVERSALISM: Understanding, appreciation, tolerance, and protection for the welfare of all people and for nature. (Protecting the environment. A world of beauty. Unity with nature. Broad-minded. social justice. Wisdom. Equality. A world with peace. Inner harmony) (9)

BENEVOLENCE: Preservation and enhancement of the welfare of people with whom one is in frequent personal contact. (Helpful. Honest. Forgiving. Loyal. Responsible. True friendship. A spiritual life. A mature love. Meaning in life) (9)

TRADITION: Respect, commitment, and acceptance of the customs and ideas that traditional culture or religion provide. (Respect for tradition. Humble. Devout. Accepting my portion in life. Moderate) (5)

CONFORMITY: Restraint of actions, inclinations, and impulses likely to upset or harm others and violate social expectations or norms. (Obedient. Self-discipline. Politeness. Honoring parents and elders) (4)

SECURITY: Safety, harmony and stability of society, of relationships, and of self. (Social order. Family security. National security. Clean. Reciprocation of favors. Healthy. Sense of belonging) (7)
} 


\section{Religious Commitment and Values Related Research}

"Religiosity has been defined as the degree to which individuals are committed to a particular religious group (Essoo and Dibb, 2004).” McDaniel and Burnett (1990) defined religiosity as "A belief in God accompanied by a commitment to follow principles believed to be set forth by God."

Research about the relation between religiosity and values has a long history. Scholars from different disciplines including marketers, psychologists, and sociologists have analyzed the relation between religion and values. In theory, values and religiosity are supposed to be linked with each other. Past studies demonstrated that religion put the emphasis on the significance of some personal values (Rokeach, 1969). According to Delener (1994), religion has an impact on personal values, attitudes and life styles, and as a result is closely related to the consumer decision making process. In short, religiosity is a significant determinate of specific personal values and consumers' ethical behaviors (Vitell and Paolillo, 2013).

Saroglou, Delpierre, and Dernelle made a meta-analysis of twenty-one studies from fifteen countries in 2004. According to this study, "values are particularly sensitive to the cultural context and the way religion is expressed within it." For instance, Universalism, using the Schwartz definition has a negative link with religiosity in mono-religious countries such as the Mediterranean ones (Portugal, Spain, Italy, Greece, Turkey, Israel). On the other hand, no relation has been found with religiosity in secularized and pluri-religious countries such as the Western European ones (Belgium). "Security was negatively related to religion in countries where an open conflict between the State and the churches existed, whereas it is unrelated or positively related to religion in other cases (Saroglou et al., 2004)." They used Schwartz's value dimensions to understand how religiosity is related to the emphasis given to values. Since the total sample size is very large, for significance testing they consider the CI value, which must not include the value of zero. Saroglou et al.'s study (2004) reveals that religiosity is positively correlated with Tradition, Conformity, and to a lesser extent, Security and Benevolence. On the other side, it is negatively correlated with Hedonism, Stimulation, Self-Direction, Universalism, Achievement and Power.

Religiosity is a subject that covers several areas related to the marketing discipline such as consumer behavior, attitudes, beliefs, feelings and experiences (Mokhlis, 2009). For instance, Wilkes, Burnett, and Howell (1986) suggested that the level of religiosity has a significant relation with some consumer lifestyles like opinion leadership, credit purchase, life satisfaction and risk avoidance. According to Delener (1990), it is one of the most crucial cultural factors and is a key influencer of buyer behavior.

In the light of all these findings, it is noteworthy that religiosity and personal values are important notions for research by marketers and social scientists in order to understand people's consumption patterns, purchase intentions and interpersonal relations in society. That is why it is hypothesized that there is a significant relationship between the value dimensions and the level of religious commitment of an individual. 
Value research of Schwartz is conducted in populations with different faiths, mainly concentrating on Christian and Jewish people. Their research focusing on the link between values and religious commitment does not draw conclusions on Muslim populations. Therefore, understanding the values of people in a country where the majority of the population is Muslim, and examining the relationship between values and religious commitment is expected to provide a valuable insight to all social scientists.

Most of the previous research has concentrated on Christian countries and tended to measure religiosity with one question on the frequency of church attendance. On the other hand, examining several Islamic scales (Alam et al., 2011; Khalek, 2007), it is observed that there is too much focus on the Koran, and those scales are not thought to be suitable for measuring the religious commitment levels of people in a secular country like Turkey. Therefore, the scale of Shukor and Jamal (2013), developed for measuring religious commitment in the context of consumer research, was used. That's why the term "religious commitment" is preferred in this article.

\section{Millennials or Generation Y}

Egri and Ralston (2004) defined generation as a "type of national subculture that reflects the value priorities." More importantly according to Balda and Mora (2011) the members of a generational subculture have similar beliefs, values, attitudes, and logical processes which shape their way of thinking, acting, reasoning, processing information, working, organizing and leading.

As a result, it is sufficient to say that the generation theory is closely related to personal values, and it is important to examine the values of a group of like-minded individuals for the behavioral sciences such as marketing, organizational behavior, education science, sociology and psychology. It is crucial for different disciplines to explore the hidden value structure of each generation and compare it with other generations.

According to Krahn and Galambos (2014); and Lazarevic (2012), "Gen Y witnessed large-scale social and economic changes and shared a relative understanding of a common destiny, memory, culture and life experiences which caused similar attitudes and beliefs to develop." It is also observed that people belonging to the same generation cohort have similar preferences and behavior, although they are residing in different parts of the world.

There is abundant research on Gen Y in the marketing field. They have a powerful aggregate spending and represent a profitable market segment. Therefore, marketers attempt to learn more about Gen Y'ers and develop strategies to influence them (Noble et al. 2009).

There are four well-known generations in the literature. The Silent Generation (or Veterans; born 1933 to 1945); Baby Boomers (born 1946 to 1964); Generation X (born 1965 to 1976); and Generation Y/Millennials (born 1977 to 1994). Schiffman and Kanuk, (2010) also noted that different experts quote different starting and ending years for the generational cohorts. There is no consensus regarding the time interval that defines the Generation Y'ers period among researchers; it is defined as 1981-2000 by Cekada (2012), 1978-1989 by Tulgan and Martin (2006), 1982-2000 by Howe and Strauss (2000) and 1977-1994 by Schiffman and Kanuk (2010). 
In this study, Gen Y'ers have been chosen as the main unit to be investigated and Schiffman and Kanuk's (2010) cohort interval (1977-1994) is accepted. Gen Y'ers form approximately one-third of the global population, and constitute the most numerous population within the workplace - between fifty and eighty million employees in the U.S. workplace are Gen Y'ers. Furthermore, it is anticipated that they will "account for 50 percent of the U.S.A. workforce by 2020 and 75 percent of the global workforce by 2030" (Meister, 2012). Another fact which increases the importance of Gen Y'ers is their significantly high purchasing power. They also constitute almost one-third of the Turkish population (Sozer, 2014).

This study focuses on the Gen Y'ers who are already in the workforce. When two qualitative studies, one conducted with Gen Y members who are at the university, and the other one with working Gen Y'ers, it has been observed that business experience may influence the values of individuals. The authors argue that the Gen Y'ers who have experienced firsthand working life may prioritize different values. Therefore, it was decided to narrow the span of age and concentrate only on working Gen Y'ers who are already and/or will be the decision makers in their companies/ society.

\section{Hypothesis Development}

Schwartz and Huismans were the first who examined the relation between religiosity and Schwartz's values in 1995. In their study, the authors conducted their research with well-educated Jews, Protestants, Catholics and people of Orthodox faith $(\mathrm{N}=1,716)$. The findings reveal that religiosity is most positively correlated with tradition values, since these values are about preserving the social order and protecting individuals against uncertainty. It is also argued that religiosity has a positive correlation with Conformity, Benevolence, and Security (see Table 5 for the summary of results). Furthermore, Schwartz and Huismans divided the sample according to gender and age; 514 participants were fourteen to twenty-nine years old (those who were fourteen to eighteen years old partially corresponded to Gen Y in 1995), and the relationship of the value dimensions with religiosity provided different results for some dimensions (see Table 2: Correlations between Religiosity and Values).

Table 2

Correlations between Religiosity and Values ( Schwarzt and Huismans 1995)

Schwarzt and Huismans 1995

\begin{tabular}{|c|c|c|c|c|c|c|c|c|c|c|c|}
\hline & $\mathbf{N}$ & 氖 & 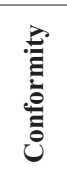 & 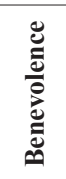 & 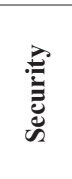 & 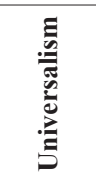 & 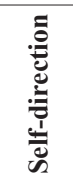 & 苞 & 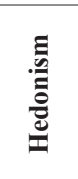 & 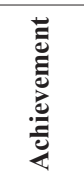 & 离 \\
\hline $\begin{array}{c}\text { Total } \\
\text { sample }\end{array}$ & 1716 & 0,54 & 0,30 & 0,15 & 0,15 & $-0,24$ & $-0,18$ & $-0,34$ & $-0,39$ & $-0,13$ & $-0,08$ \\
\hline $\begin{array}{c}14-29 \\
\text { years old }\end{array}$ & 514 & 0,34 & 0,22 & 0,13 & 0,15 & $-0,04 *$ & $-0,14$ & $-0,33$ & $-0,25$ & $0,03 *$ & $-0,07^{*}$ \\
\hline
\end{tabular}


It should be noted that the research of Schwartz and Huismans (1995) and that of Saroglou et al. (2004) like most of the other studies were conducted on Christian, particularly Catholic denominations. In this study, findings will be specific to Gen Y and to a country with a predominantly Muslim population. After having identified the value dimensions for the Turkish working Gen Y'ers through factor analysis, the relation of the value dimensions with religiosity will be explored in a Muslim country context.

H1: There is a significant relation with each value orientation and one's religious commitment.

Similar to other studies in the literature, Schwartz and Rubel's (2005) findings reveal that the values may differ according to gender. In their study conducted with people from different age groups, the power, stimulation, hedonism, achievement and self-direction values are found to be more important for men, whereas benevolence and universalism values proved to be more important for women. According to their results, culture moderates all gender differences and sample types. They demonstrated that the measurement instruments have minor influences as well. Gilligan (1982) also argues that women show more ethical concerns and responsibility, while men focus more on the ethics of rights based on justice and fairness. A later study by Schwartz (2012) indicates that women are more caring for the welfare of in-group members and men are more caring in attaining and exploiting status and power. That is why it was decided to test whether the value dimensions differ according to gender in the Turkish working Gen Y sample or not.

As gender has been indicated as a discriminating factor related to the importance given to each value dimension, a t-test analysis will be carried out to explore the gender differences specific to Gen Y in the study.

H2: The importance attributed to each value orientation will differ between male and female respondents.

\section{Research Design and Methodology}

In this section, information on the scale development, sample selection and data collection and validity measurements have been provided.

\section{Scale Development to Measure Values and Religiosity}

As the first step, a thorough literature review was carried out on values and religious commitment. The existing scales and measurement methods have been investigated. As a result, the scale to measure the values of the Turkish Gen Y'ers consisted of Schwartz's Value Items (1994), and the ten new items identified in the previous research conducted by the authors (2015). Within the previous research, the authors conducted in depth and focus group interviews with 40 respondents. Content analysis was applied to the data gathered. At the end, 50 meta-themes were determined, and categorized under eight main dimensions. Two judges with a marketing background placed 50 meta-themes under the given dimensions, and their agreement level was found to be reliable $(86.63 \%)$.

The SVS contains 57 value items in total. The translation of the questionnaire was done by the researchers, and it has been reviewed by two English professors and one 
marketing professor. The scale prepared contained 67 value items - 57 from Schwartz's SVS (1994) and nine from the qualitative research (Justice, Trust in others, Sincerity, Hard-working, Productivity, Dynamism, Well groomed, Desire to be loved and Empathy), and one new item, namely "nationalism," was added by the researchers. A pilot study was conducted with 112 respondents. It was observed that some of the value items were found to be similar in terms of meaning in Turkish and therefore it was difficult to differentiate among such as "justice and social justice." Some were not perceived as values by the respondents, such as "intelligent," "healthy" and "clean." Furthermore, some of the value items of Schwartz were found difficult to understand, such as "mature love," "a world of beauty," "reciprocation of favors," "meaning in life" or "accepting my portion in life." Therefore they were eliminated. As a result of the pilot study, a forty-nine-item seven-point scale was developed: forty-two value items from Schwartz and seven outlined by Turkish Gen Y'ers, namely; justice, hard-working, dynamism, productivity, trust in others, sincerity, and nationalism.

In the literature, most research studies cover the Christian countries, and previously used measurement instruments related to measuring religiosity are mostly based upon the frequency of church attendance. Schwartz and Huismans's (1995) study as well measures the level of religiosity with a single question about church attendance. Turkey is the only secular country of which $99 \%$ of the population is Muslim. Attendance at the mosque on Friday is the compulsory duty of men only. On the other hand, several Islamic scales (Alam et al., 2011; Khalek, 2007) focus too much on the Koran, and are not suitable for measuring the religiosity levels in a secular country in daily life. This study focuses on religious commitment, emphasizing the importance of adhering to one's religious beliefs as a basis for action in daily life, which can include the way one behaves in the society. The scale of Shukor and Jamal (2013), developed for measuring religious commitment in the context of consumer research, was chosen to be used in the study. Furthermore, two overall self-ranking questions which aim to measure the level at which the respondents define themselves in terms of "being religious" and "being faithful" in their daily lives were taken from a report by the Fetzer Institute (2003).

\section{Sample and Data Collection Procedure}

Instead of examining all the adult population, the researchers decided to concentrate on the working young people (between 24-40 years of age) who are the decision makers, and who will also increase in their influence as they advance in their careers. In marketing literature that group belongs to the Gen $\mathrm{Y}$ which is an important generation cohort widely examined. An online survey with a total of sixty-one questions including the demographic questions was prepared. The survey was distributed through the social media, and the convenience sampling technique was used. Acknowledging that Gen $\mathrm{Y}$ is a tech-savvy generation (Tulgan and Martin, 2006), the social media was chosen to distribute the questionnaire. At the end of a two months period (September-October 2015), 502 people completed the survey. Gen Y'ers (born between 1977 and 1994) who were working at the time were selected for further analysis, yielding 405 com- 
plete questionnaires. In accordance with Krejcie and Morgan's (1970) study, when the population $(\mathrm{N})$ was higher than one million with a standard error of 0.05 , the minimum sample size should be 384 . Later the presence of outliers was assessed through SPSS. After all these analyses, 361 respondents' answers were found to be appropriate for further examination. In terms of the descriptive statistics, the number of male $(\mathrm{N}=180)$ and female $(\mathrm{N}=181)$ respondents was found to be suitable for the additional analysis. The respondents' education level was high when compared to the average of Turkey; $95 \%$ of the respondents had a university or higher level of education. That's why the results were interpreted taking this fact into consideration.

\section{Factor Analysis and Validation of Measures}

Univariate normality was assessed by checking the skewness and kurtosis coefficients. The most commonly accepted value of univariate normality is between -3 and 3 (Tabachnick and Fidell, 1996). All of the variables demonstrated skewness and kurtosis coefficients within this given interval. All the variables had univariate normal distributions. A multicollinearity analysis was conducted to all the items in order to show whether there is an unexpectedly high correlation between any two of them. The VIF scores demonstrated that there are no multicollinearities since they were all below ten.

The reliability coefficient for the value item scale was found to be 0.91 . An exploratory factor analysis was conducted with a varimax rotation. Kaiser-Meyer-Olkin was used to measure the sampling adequacy for factor analysis. Varimax rotation was preferred since it maximizes high loadings and minimizes low loadings for each factor. All 49 items were subject to a factor analysis. The results reveal that ten factors accounted for $62.61 \%$ of the total variance. The accepted standard for the significant factor loadings was 0.40 within this study. This is in line with earlier studies in the domain (Gregory and Leo, 2003; Küçükusta, Mak, and Chan, 2013). Only one of the items (broad-minded) was deleted due to the poor factor loading resulting in only 48 items examined in the study. The ten value dimensions obtained in this study as a result of the factor analysis and their defining goals have been summarized in Table 2. (see Table 3: Personal Value Types of Working Gen Y'ers).

The other scale used in the research, namely the religiosity scale, consisted of five statements (a seven point Likert scale: strongly agree 7, strongly disagree 1). An exploratory factor analysis with a varimax rotation was performed on the scale. The analysis yielded one single factor. The Cronbach's alpha coefficient for this construct was found to be 0.83 .

\section{Findings Related to Value Dimensions}

It should be noted that Schwartz's sample mainly consisted of Gen X members, and the studies were conducted with people from different religions other than Islam. However, it is worth comparing the results of the studies to observe the similarities and differences among Schwartz's and this study (Schwartz, 1992, 1994, 2005, 2012).

It is seen that among the ten value dimensions identified for Turkish Gen Y'ers, only one is named similar to that of Schwartz - tradition - as it exactly represents the same phenomena though covering different items for the Turkish sample. 
Table 3

Personal Value Types of Working Gen Y'ers

\begin{tabular}{|c|c|c|c|c|}
\hline \# & Personal Value Types & Defining Goal & $\begin{array}{l}\text { Cronbach } \\
\text { alpha }\end{array}$ & $\begin{array}{l}\text { Mean } \\
\mathrm{N}: 361\end{array}$ \\
\hline 1 & $\begin{array}{l}\text { INDEPENDENCE } \\
\text { Self-respect. Freedom. Privacy. Justice. (4) }\end{array}$ & $\begin{array}{l}\text { Independent behavior } \\
\text { and thought related to } \\
\text { one's own life }\end{array}$ & 0,78 & 6,50 \\
\hline 2 & $\begin{array}{l}\text { TRUST } \\
\text { Trust to others. True friendship. Honesty. } \\
\text { Sincerity. (4) }\end{array}$ & $\begin{array}{l}\text { Integrity, frankness } \\
\text { and reliability of } \\
\text { relationships }\end{array}$ & 0,72 & 6,18 \\
\hline 3 & $\begin{array}{l}\text { HUMANITARIAN } \\
\text { Helpful. Inner harmony. Reciprocation of } \\
\text { favors. Politeness. Equality. Loyalty (6) }\end{array}$ & $\begin{array}{l}\text { Caring about inner } \\
\text { harmony as well } \\
\text { showing kindness and } \\
\text { fairness towards others }\end{array}$ & 0,79 & 6,06 \\
\hline 4 & $\begin{array}{l}\text { SUCCESS } \\
\text { Hardworking. Self-discipline. Responsible. } \\
\text { Curious. (4) }\end{array}$ & $\begin{array}{l}\text { Personal achievement } \\
\text { through one's own } \\
\text { merits }\end{array}$ & 0,72 & 5,99 \\
\hline 5 & $\begin{array}{l}\text { PEACE WITH THE WORLD } \\
\text { Unity with nature. Protecting the } \\
\text { environment. A world with peace. (3) }\end{array}$ & $\begin{array}{l}\text { Care for and } \\
\text { responsibility about the } \\
\text { world }\end{array}$ & 0,86 & 5,65 \\
\hline 6 & $\begin{array}{l}\text { TOLERANCE } \\
\text { Forgiving. Humble (2) }\end{array}$ & $\begin{array}{l}\text { Mercy and modesty } \\
\text { towards others }\end{array}$ & 0,69 & 5,63 \\
\hline 7 & $\begin{array}{l}\text { LEADERSHIP } \\
\text { Daring. Dynamism. Influential. Creativity. } \\
\text { Ambition. Authority. Wisdom. Productivity. } \\
\text { (8) }\end{array}$ & $\begin{array}{l}\text { Impact on society } \\
\text { through initiative and } \\
\text { wisdom }\end{array}$ & 0,85 & 5,58 \\
\hline 8 & $\begin{array}{l}\text { SELF-GRATIFICATION } \\
\text { Self-indulgent. Choosing own goals. } \\
\text { Exciting life. Pleasure. A varied life. (5) }\end{array}$ & $\begin{array}{l}\text { Pleasure and } \\
\text { excitement in life }\end{array}$ & 0,82 & 5,47 \\
\hline 9 & $\begin{array}{l}\text { SOCIAL CONFORMITY } \\
\text { Preserving my public image. Moderate. } \\
\text { Social order. Social recognition. (4) }\end{array}$ & $\begin{array}{l}\text { Obedience, desire to } \\
\text { be in line with social } \\
\text { norms }\end{array}$ & 0,66 & 4,97 \\
\hline 10 & $\begin{array}{l}\text { TRADITION } \\
\text { Devout. National security. Obedient. } \\
\text { A spiritual life. Respect for traditions. } \\
\text { Honoring parents and elders. Sense of } \\
\text { belonging. Nationalism. (8) }\end{array}$ & $\begin{array}{l}\text { Respect, compliance } \\
\text { and preservation of the } \\
\text { customs and ideas that } \\
\text { one's culture or religion } \\
\text { provides }\end{array}$ & 0,71 & 4,46 \\
\hline
\end{tabular}


The "Independence" value dimension representing independent behavior and thought related to one's own life proved to be important in the qualitative study carried out by researchers (2015). Turkish Gen Y'ers have a strong desire to obtain financial and social independence to be able to direct their life as they wish and care about their private life. To be able to do so, they need a "fair" environment that will permit them to strive for their independence. Self-respect, privacy, and freedom are the values that are common to Schwartz's self-direction dimension; however, this value dimension has been enlarged for the Turkish sample by adding the "justice" value item.

"Trust" is an important value dimension that is unique to this study. It had also been emphasized strongly in the qualitative study. The search for integrity, frankness, and reliability in relationships are important needs, highlighted by the Gen Y'ers. The World Value Survey (2012), which is conducted by Esmer (2012) in Turkey, also come up with similar results.

The "humanitarian" value dimension is also reported only in this study, and represents the search for inner harmony as well as showing kindness and fairness towards others.

The "Success" value dimension is also unique to this study, emphasizing personal achievement through one's own merits. Therefore, being hardworking, self-disciplined, curious and responsible are the qualities that one should have in order to have success in life. They are basically inner-directed rather than demonstrating competence according to social norms. Therefore, it is different from the "achievement" value dimension of Schwartz.

The "peace with the world" dimension covers only three value items which exist in the "universalism" dimension of Schwartz (unity with nature, protecting the environment and a world with peace), therefore it is considered to be oriented towards care and responsibility for the world rather than representing universal values.

"Tolerance" containing two value items proved to form another value dimension emphasizing the tolerance and humility towards others as important aspects. The tolerance value dimension does not exist in Schwartz and "forgiving" and "humble" value items appear in separate dimensions in his study.

The "Leadership" value dimension is about creating an impact on society rather than exercising sole power and control over others. It contains wisdom, daring, dynamism, influence, ambition, authority, creativity and productivity as the main value items essential to leadership.

The "Self-gratification" value dimension contains a mixture of Schwartz's stimulation and hedonism motivational value items. It is directed towards the desire for pleasure and excitement in life. Therefore, it includes self-indulgence, choosing one's own goals, an exciting life, pleasure and varied life items. Although the "choosing one's own goals" value item is available in the "self-direction" dimension in Schwartz's study, it is still meaningful to be in the self-gratification dimension since it provides enchantment to these youngsters in their daily and working lives. 
The next dimension is named "Social Conformity" it differs from the conformity dimension of Schwartz. It contains value items such as "moderate," "preserving my public image," "social order," "social recognition;" it emphasizes one's desire to be in line with social norms and refers to the standing of the individual in society.

"Tradition" is the value dimension which includes items such as "devout" and "respect for traditions" similar to Schwartz's study, but it enlarges the tradition concept by adding "honoring parents and elders," "sense of belonging," "obedience," "a spiritual life," and "nationalism" value items that make sense for Turkish traditionalists. Furthermore, honoring elders and obedience are part of Turkish traditional culture.

In this study, the respondents are asked to rate the importance of each value item in shaping their life (1: not important at all, 7: very important). The top ten value items and the least important ones are listed below in Table 4. Furthermore, it is worth noting that the standard deviation for each of these top ten items is between 0.6 and 0.9 , a measurement being lower than the standard deviations of all other items.

Table 4

The 10 Most and Least Important Value Items for Working Gen Y'ers

\begin{tabular}{l|l|c|c|l}
\hline$\#$ & ITEM & Mean & St.D. & DIMENSION \\
\hline $\mathbf{1}$ & Justice * & 6,70 & 0,591 & INDEPENDENCE \\
\hline $\mathbf{2}$ & Honest * & 6,54 & 0,726 & TRUST \\
\hline $\mathbf{3}$ & Privacy & 6,44 & 0,864 & INDEPENDENCE \\
\hline $\mathbf{4}$ & Self respect & 6,44 & 0,864 & INDEPENDENCE \\
\hline $\mathbf{5}$ & Independence * & 6,42 & 0,904 & INDEPENDENCE \\
\hline $\mathbf{6}$ & Sincerity * & 6,38 & 0,871 & TRUST \\
\hline $\mathbf{7}$ & Inner harmony * & 6,31 & 0,959 & HUMANITARIAN \\
\hline $\mathbf{8}$ & Pleasure * & 6,30 & 0,904 & SELF GRATIFICATION \\
\hline $\mathbf{9}$ & True friendship * & 6,24 & 1,037 & TRUST \\
\hline $\mathbf{1 0}$ & Responsible * & 6,23 & 0,923 & SUCCESS \\
\hline $\mathbf{.}$ & $\ldots$ & $\ldots$ & $\ldots$ & $\ldots$ \\
\hline $\mathbf{3 9}$ & Sense of belonging * & 5,20 & 1,519 & TRADITION \\
\hline $\mathbf{4 0}$ & Social order * & 5,19 & 1,439 & SOCIAL CONFORMITY \\
\hline $\mathbf{4 1}$ & Preserving my public image & 5,10 & 1,439 & SOCIAL CONFORMITY \\
\hline $\mathbf{4 2}$ & Respect for traditions * & 4,71 & 1,629 & TRADITION \\
\hline $\mathbf{4 3}$ & Self indulgent & 4,63 & 1,706 & SELF GRATIFICATION \\
\hline $\mathbf{4 4}$ & Authority * & 4,58 & 1,628 & LEADERSHIP \\
\hline $\mathbf{4 5}$ & Social recognition * & 4,30 & 1,687 & SOCIAL CONFORMITY \\
\hline $\mathbf{4 6}$ & Nationalism * & 4,06 & 2,062 & TRADITION \\
\hline $\mathbf{4 7}$ & Obedient * & 3,26 & 1,768 & TRADITION \\
\hline $\mathbf{4 8}$ & Devout * & 3,12 & 1,994 & TRADITION \\
\hline & & & & \\
\hline
\end{tabular}


Furthermore, the participants are asked to choose only five of the value items as the most important ones for themselves. The results are very coherent: among the first ten items with the highest mean, eight of them are at the top of the priority list (marked with a star). Among the ten items that have the lowest mean, again eight of them (marked with a star) are rated as the least important values among all value items. These results have similarities with the study of Ralston et al. (2011).

One of the interesting points is that the Gen Y members attach a high importance to environmental protection (having the twelfth highest mean: 6.20). However, they do not include this item in their top five priority list. This result can be interpreted as that, although they care about the environment, the values of justice, independence, honesty etc. are so crucial that those values can easily outrank environmental protection in terms of priority.

Examining the importance of value items, it can also be observed that the "independence" dimension, having in total four value items at the top of the list, is very important for Gen Y'ers. Furthermore, three of the most important value items are from the "trust" dimension. On the other side, when the means of the least important values are investigated for the Turkish Gen Y'ers, five of them, namely a sense of belonging, devotion, respect for traditions, nationalism and obedience belong to the "tradition" value dimension. Furthermore, three of them belong to the "social conformity" dimension (social recognition, preserving my public image, social order). Past studies like WVS's 2012 Turkey report demonstrated that Turkey is one of the countries that shows the lowest level of trust in others. This is a proof for the priority given to the desire for trust in the young generation.

On the other hand, one of the most frequently stated value items in this study is "justice," and this is not included in Schwartz's values list. This result may indicate the need of the new generations for "justice."

They ask for "respect for their private life." Gen Y members want to enjoy their life. Referring to the results of previous qualitative studies by the researchers $(2014 ; 2015)$ it can also be argued that Gen Y'ers have a strong desire to be independent and find a balance between their private and work life.

\section{Findings Related to Religious Commitment}

Examining religious commitment, it can be concluded that Turkish Gen Y'ers believe in God, but are not keen on strictly following the rules (see Table 5: The Mean Distribution of Religiosity Scale). Furthermore, the two self-ranking questions reveal that a large majority of Turkish Gen Y'ers define themselves as believing in God (85\%); however, the percentage / ratio of those who view themselves as "religious" is low (48\%).

As most of them do not follow the rules of the religion strictly, the working Gen Y'ers do not consider themselves to be religious but they are believers/ have faith. It should be noted that the survey sample consists of participants with a higher education. These findings are also consistent with the results of the 2012 Turkey report carried out by Esmer for the World Values Survey. Since 95\% of the sample of the study consists of people with a bachelor's degree or higher it was quite expected that these Gen Y members would have a lower level of devoutness. 
Table 5

Mean Distribution of the Religiosity Scale

\begin{tabular}{|l|c|c|c|}
\hline \multicolumn{1}{|c|}{ Religiosity Scale } & $\begin{array}{c}\text { N } \\
\text { (Valid) }\end{array}$ & Mean & St. Dev. \\
\hline I believe in Allah (God). & 361 & 5,69 & 2.063 \\
\hline $\begin{array}{l}\text { It is important for me to follow Allah's commandments } \\
\text { conscientiously. }\end{array}$ & 361 & 3,70 & 2.196 \\
\hline I carefully avoid shameful acts. & 361 & 3,55 & 2.038 \\
\hline $\begin{array}{l}\text { I always perform my duty as Muslim (e.g. pray five } \\
\text { times a day, fasting during the month of Ramadhan, } \\
\text { pilgrimage to Mecca) to Allah. }\end{array}$ & 361 & 3,27 & 2.047 \\
\hline $\begin{array}{l}\text { Religious beliefs influence all my dealings with } \\
\text { everyone. }\end{array}$ & 361 & 2,46 & 1,827 \\
\hline
\end{tabular}

When they are asked to state their level of religiosity, $48 \%$ of the participants stated that they were religious to a certain extent; only one percent was very religious, whereas $51.8 \%$ of the sample stated that they were not religious at all. These results are in line with the analysis of the religious commitment scale. As it can be observed from Table 5, the participants are not likely to perform their full duties as Muslims (mean: 3.27), which clearly shows that their level of religious commitment is low. However, the situation is different when they are asked to indicate whether they have faith or not. According to the results, although more than half say that they are not religious at all, $85 \%$ state that they have faith to a certain extent, of which $14 \%$ report they have high faith. Only $15 \%$ do not have a faith at all. These findings are again consistent with the results of the religiosity scale which demonstrated that most of these youngsters have faith in Allah/God (mean: 5.69/7.00). The majority of well-educated working Gen Y'ers do believe in Allah, but do not perform the duties commanded by religion. It has to be noted that Turkey is unique in being the only secular Muslim country, and its strategic location between Europe and Middle East.

\section{Hypothesis Testing}

After the development of the value dimensions for the Turkish Gen Y'ers, the relationship of each value dimension with religiosity was explored. To identify the direction and strength of the relation between the value items and religiosity and to test the first ten hypotheses, the Pearson correlation analysis was used. The correlation factor matrix demonstrated that the highest positive correlation was between "tradition" $(0.612)$ and religious commitment. There was a lesser but positive correlation between "social conformity" (0.270), "success" (0.159), "leadership" (0.133), tolerance $(0.128)$ and religiosity. (see Table 6: Correlation Matrix of Values Dimensions with Religiosity.) 
Table 6

\section{Correlation Matrix of Values Dimensions with Religiosity}

\begin{tabular}{|c|c|c|c|c|c|c|c|c|c|c|}
\hline \multicolumn{11}{|c|}{ Descriptive Statistics } \\
\hline & 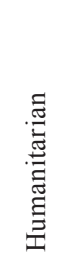 & 胥 & 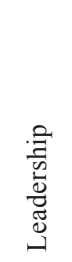 & 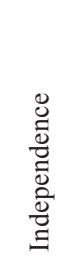 & 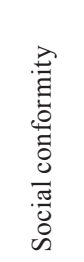 & $\begin{array}{l}w \\
0 \\
0 \\
心 \\
\omega\end{array}$ & 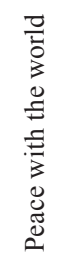 & 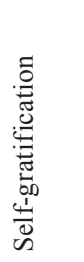 & 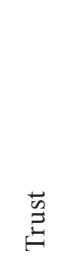 & 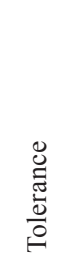 \\
\hline Religiosity & ,071 &, $612^{* *}$ &, $133^{*}$ &,- 054 & $270^{* *}$ &, $159^{* *}$ &, 028 &,- 089 &, 058 &, $128^{*}$ \\
\hline
\end{tabular}

**. Correlation is significant at the 0.01 level (2-tailed).

*. Correlation is significant at the 0.05 level (2-tailed).

The relationship between the "Tradition" value dimension and one's level of religiosity was found to be the strongest, being similar to Schwartz and Huismans's (1995) study conducted with people from different religions. Their study also supported that the level of religiosity or commitment to religion was most positive for those giving priority to "traditional" value items. The value items attributed to "tradition" in this study, being devout and obedient, respecting traditions and honoring the elderly, desire for a spiritual life and sense of belonging are the value items that can be correlated with religiosity. The positive and significant correlation between religiosity and social conformity values was also consistent since the latter involve an acceptance of social norms as expected in religious commitment. The positive and significant correlation between religiosity and tolerance values was consistent, since the tolerance dimension covering "forgiving" and "humble" value items were mostly covered in many religions. Although the direction has been found negative for both the independence and selfgratification dimensions, their relationship with religious commitment did not result as significant. The "humanitarian" and "peace with the world" value dimensions were not correlated with one's religious commitment. It is interesting to observe that there was a positive and significant correlation of religiosity with success and leadership value dimensions. Referring to the literature, in several studies of Schwartz and in his study with Huismans, a negative correlation was found with the power dimension as defined by Schwartz (-0.08) and with his achievement dimension $(-0.13)$. However, it is worth noting that this study created new value dimensions with a different content so that the "Success" value dimension contained values like being hard-working, self-disciplined, and having responsibility that were defined as inner directed. These value items are very much related with what religion suggests to people. Furthermore, it may be argued that success is very important for members of this generation and does not counteract religious commitment. The fact that the "leadership" value dimension and religiosity were shown to have a positive significant relationship may reveal new facts about this specific Generation cohort. Previously it was believed that religiosity would keep people away from earthly ambitions. However, it can be proposed that even Gen Y members 
with religious commitment wish to be creative, productive, daring and dynamic, with ambition in order to obtain authority and have leading roles in society. As a result, $\mathrm{H} 1$ is partially accepted where tradition, social conformity, tolerance, leadership and success proved to have a positive correlation with one's religious commitment.

The results have also been evaluated with respect to the gender differences so as to test $\mathrm{H} 2$. In order to see whether the gender difference is significant over different value dimensions and religiosity, a t-test analysis was applied to the collected data. As a result of the t-test analysis, the present study demonstrated that well educated women from the working class of Gen Y in Turkey give more importance to humanitarian concerns, success, peace with the world, self-gratification, tolerance, trust and independence value dimensions; whereas men score significantly higher than women on the social conformity value dimension. There are no differences in terms of gender for other dimensions. (see Table 7: Differences in Personal Values by Gender.)

\section{Table 7}

\section{Differences in Personal Values by Gender}

\begin{tabular}{|c|c|c|c|c|c|c|c|c|c|c|c|}
\hline & 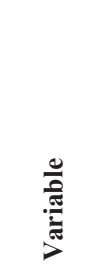 & 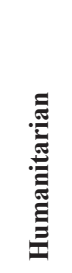 & 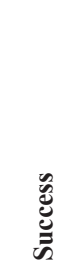 & 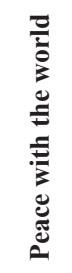 & 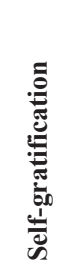 & 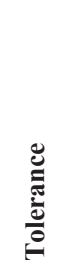 & 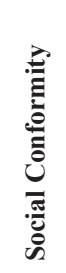 & 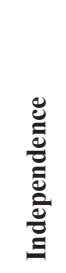 & $\vec{E}$ & 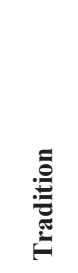 & 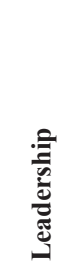 \\
\hline & $\mathrm{T}$ & $-4,07$ & $-2,82$ & $-5,16$ & $-2,82$ & 2,23 & 2,01 & -3.37 & $-3,88$ & $-0,88$ & $-1,13$ \\
\hline & $\mathbf{P}$ & 0,00 & 0,01 & 0,00 & 0,01 & 0,03 & 0,05 & 0,00 & 0,00 & 0,93 & 0,26 \\
\hline \multirow{2}{*}{ Mean } & Male & 5,90 & 5,88 & 5,39 & 5,34 & 5,50 & 5,09 & 6,39 & 6,03 & 4,46 & 5,54 \\
\hline & Female & 6,23 & 6,11 & 5,92 & 5,60 & 5,76 & 4,85 & 6,61 & 6,33 & 4,47 & 5,64 \\
\hline
\end{tabular}

\section{Limitations of the Study and Suggestions for Further Research}

The study concentrates on working Gen Y'ers. However, it may be worthwhile to observe the values and religious commitment of younger Gen Y'ers who are still in the education process in order to observe whether significant differences exist here or not.

It is also pointed out that the education level of the sample is high compared to the general average of the Turkish population. However, as the aim of the study was to find out the values and religious commitment of the future managers/decision makers of the country the results still shed light on several issues. On the other hand, it will certainly be valuable to carry out further research with a sample representing the general picture of the Gen Y'ers from different education levels in Turkey. Further analysis would help to assess the effect of education level on the values and religious commitment.

The sample of the study consists of participants with faith, but the percentage of those who consider themselves as religious is low. Therefore, it can be argued that the 
values of more religious Gen Y'ers and the value items that they give more importance to may be different. Therefore, it may be suggested to conduct research with a more religious group of Gen Y'ers may lead to detect the differences.

This study was carried out only in Turkey. Cross-cultural research covering countries with Muslim populations may help to compare and contrast the results provided in this study. It is important to note that values and their meaning may differ from one country to another as well as within the Gen Y profiles. Therefore, a well-structured qualitative research is essential to understand conceptually the meaning of each value in order to make the necessary preparations for scale translation and adaptation. Furthermore, a longitudinal research may reveal the changing values in the society.

The notion of "being faithful" as opposed to "being religious" is not studied in other countries where different religions are dominant. Therefore, such a study may shed light on the changing perceptions and tendencies of populations relative to belief structure.

A final but important point to mention is the need for a specific religious commitment scale especially to be used in Islamic countries with a secular approach. Although there are different scales used for populations with different religions, especially for the Christian and Jewish religions, the scales for Islamic populations need to be developed.

Another issue to be investigated is whether the values of Gen Y'ers are converging due to globalization, irrespective of their religion. Therefore, a further research to be conducted in a multi-religious country that has a highly globalized economy such as Hong Kong is under consideration.

\section{Expected Theoretical Contributions of the Study}

One of the main theoretical contributions of the study is expected to be the development of a values scale specific to Gen Y. The SVS is adapted and new value dimensions with a different distribution of value items have been proposed. Another contribution is the finding related to the relationship between values and religious commitment in a secular country with Muslim population.

Turkey presents a unique case of a secular country with seventy million people of which 99 percent are Muslim. As a big potential market for many global marketers, Turkey has around thirty-five million Gen Y members. Understanding their value priorities and religious commitment may provide insight to global marketers who intend to target them as internal and external customers. Therefore, the study mainly concentrates on investigating the values of Turkish people with a specific focus on Gen Y.

The previous research, especially that of Schwartz which opened the way for value studies in several countries, used university students, teachers, and some adults during the 1998-2003 period, covering mostly Generation X members. Although this study cannot be compared statistically with the previous ones, it may contribute in terms of observing the similarities and differences related to values and religiosity between generational cohorts.

Values are created in the society and certain values are expected to have more importance in different cultures. Therefore, the direct translation of certain values into 
different languages may often not be satisfactory. Among seven out of the ten items added to the scale have been found significant and important for Turkish Gen Y'ers. The value dimensions and items of Schwarz are checked at different times and in different cultural settings as a predefined set of given dimensions. In this study, the value items taken from Schwartz's list of values, together with those added, have been analyzed through factor analysis, and ten dimensions have been identified. A scale specific to Gen Y members with a total of forty-eight items has been created and the validity has been found to be high (91\%). Although there are similarities with the value dimensions of Schwartz, they are not identical, and this study presents certain value dimensions that are new, such as "trust" and "tolerance," which are significant and meaningful at the present date.

Additionally, the study reveals the most important values specific to Gen Y. Independent of the religion and culture, the effect of globalization may have created certain common values for Gen Y members all around the world. The exploration of those values specific to this generation may provide different insights for academics and businesses.

Another expected contribution of the study is the introduction of the debate: Are "being religious" and "having faith" two different concepts in the mind of the individuals? Therefore, two questions have been added to the survey and were tested. Although there is a rising trend of increasing religiosity or the intensity of religious commitment in many countries, including Turkey, some of the Turkish Gen Y members state that they do not strictly follow religious rules but are believers. This interesting finding should be examined in other countries with people belonging to different religions.

\section{Final Remarks and Managerial Implications}

The results of the study provide important insights about the value systems of Gen Y. It is possible to deduct many conclusions related to different social sciences such as psychology, sociology, marketing and management. For the purpose of this article, the implications that are thought to be more prevalent are highlighted below.

The emphasis given to corporate codes of ethics continues to increase in large corporations (Schwartz, 2005). A corporate code of ethics or content is defined by most of the scholars as a "written, distinct, and formal document which consists of moral standards that help guide employee or corporate behavior" (Schwartz, 2001). When creating a code of ethics, the value systems and priorities of existing employees will be valuable. Thus, the results of this study may be beneficial during the recruitment, placement and training of prospects and lor existing personnel in accordance with the code of ethics. Furthermore, as the values and ethical behavior have proved to have correlations (Barnett and Karson, 1987; Fritzsche, 1995; Fritzsche and Oz, 2007), the understanding of the values and their perception of religious commitment may help businesses in designing their marketing messages to tap into the ethical concerns of their customers.

This study concentrating on working Gen Y'ers in Turkey clearly demonstrates that the top priority for them is "independence." As was supported by the previous qualitative study, the Gen Y'ers have high self-respect and want to be independent economically 
and socially. These results are consistent with Tulgan and Martin's (2001) study that states that Gen Y'ers prioritize "self-esteem" and "independence." Moreover, the results demonstrated that they highly value "justice" and look for "fair treatment." One of the other strong outcomes of the research is the desire of this cohort to have a clear separation of work and private life. Similar to past studies, employment is proven to be a tool rather than an objective. It was demonstrated that for Gen Y'ers their job is a source to compensate their lifestyle (Kerslake, 2005; Morton, 2002). They are not tolerant of requirements that do not respect their private life. Wolburg and Pokrywczynski's study (2011) also put forward the idea that Gen Y'ers are keen on spending time with their families instead of working long and stressful hours at work. Under ideal circumstances, they can be responsible and hard working in order to achieve success, which will in turn lead them to obtain economic freedom.

Turkish Gen Y'ers give a lot of importance to "honesty" and "sincerity." Morton (2002) stated they expect to receive and give loyalty, not based on the years they spend in a company, but on the honesty and respect they receive. "They build loyalty based on their sincerity, not on the length of work" (Kerslake, 2005). In the work environment as well as in the promotional messages targeting them, this aspect needs to be taken into consideration. Brand promises need to be delivered with integrity in order to gain their confidence and create brand loyalty.

On the other hand, as past studies demonstrated, they also do not tolerate authority (Tulgan and Martin 2001). This study demonstrates that they are not "devout" and "obedient," which is very much in line with their independence desire. The organizations' hierarchical structure needs to be revised so that more autonomy may be given, and participation in decision making needs to be encouraged to motivate this Generation's members. Furthermore, fairness and equal opportunity are demanded by Gen Y'ers as part of a satisfactory work environment.

This study is conducted in an emerging secular country with a Muslim population focusing on working Gen Y'ers. It offers valuable information about the values of Gen Y members who have a strong purchasing power, form the most numerous cohort and are/will be the decision makers in society. Therefore, longitudinal research in different cultural settings may provide numerous benefits and shed further light for academics and businesses.

\section{References}

Akaah, I. P. and Lund, D. (1994). "The Influence of Personal and Organizational Values on Marketing Professionals' Ethical Behavior," Journal of Business Ethics, 13(6): 417-430.

Ajzen, I. (1991). "The Theory of Planned Behavior," Organizational Behavior and Human Decision Processes, 50(2): 179-211.

Alam, S.S., Mohd, R., and Hisham, B. (2011). "Is Religiosity an Important Determinant on Muslim Consumer Behavior in Malaysia?" Journal of Islamic Marketing, 2(1): 83-96.

Balda, J.B. and Mora, F. (2011). "Adapting Leadership Theory and Practice for the Networked, Millennial Generation," Journal of Leadership Studies 5(3): 13-24. 
Barnett, J.H. and Karson, M.J. (1987). "Personal Values and Business Decisions: An Exploratory Investigation," Journal of Business Ethics, 6(5): 371-382.

Brown, L.B. (1988). The Psychology of Religious Belief. London: Academic Press.

Cekada, T.L. (2012). “Training a Multigenerational Workforce,” Professional Safety, 57(3): 40-44.

Delener, N. (1990). "The Effects of Religious Factors on Perceived Risk in Durable Goods Purchase Decisions," Journal of Consumer Marketing, 7(3): 27-38. doi: http://dx.doi.org/10.1108/ EUM0000000002580.

------, (1994). "Religious Contrasts in Consumer Decision Behaviour Patterns: Their Dimensions and Marketing Implications," European Journal of Marketing, 28(5): 36-53.

doi: http://dx.doi.org/10.1108/03090569410062023.

Doran, C.J. (2009). "The Role of Personal Values in Fair Trade Consumption," Journal of Business Ethics, 84: 549. DOİ:10.1007/s10551-008-9724-1.

Egri, C.P. and Ralston, D.A. (2004). "Generation Cohorts and Personal Values: A Comparison of China and The United States," Organization Science, 15(2): 210-220.

England, G. (1967). "Personal Value Systems of American Managers," Academy of Management Journal, 10(1): 53-68.

Esmer, Y. (2012). “WV6_Results_Turkey 2012.” Retrieved 29 March 2015 from World Values Survey Association. www.worldvaluessurvey.org.

Essoo, N.and Dibb, S. (2004). "Religious Influences on Shopping Behavior: An Exploratory Study," Journal of Marketing Management, 20: 683-712.

Feather, N.T. (1995). "Values, Valences, and Choice: The Influence of Values on the Perceived Attractiveness and Choice of Alternatives," Journal of Personality and Social Psychology, 68: $1135-1151$.

Fetzer Institut, (2003). "Multidimensional Measurement of Religiousness/Spirituality for Use in Health Research.” A Report of the Fetzer Institute/ National Institute on Aging Working Group.

Fritzsche, D. (1995). "Personal Values: Potential Keys to Ethical Decision Making," Journal of Business Ethics, 14, no. 11: 909-922.

Fritzsche, D. and Oz, E. 2007. "Personal Values' Influence on the Ethical Dimension of Decision Making," Journal of Business Ethics, 75(4): 335-343.

Gilligan, C. (1982). In a Different Voice: Psychological Theory and Women's Development. Cambridge MA: Harvard University Press.

Gregory, G.D. and Leo, M. (2003). "Repeated Behavior and Environmental Psychology: The Role of Personal Involvement and Habit Formation in Explaining Water Consumption," Journal of Applied Social Psychology, 33: 1261-1296. doi: 10.1111/j.1559-1816.2003.tb01949.x

Homer, P.M. and Kahle, L.R. (1988). "A Structural Equation Test of the Value-attitude Behavior Hierarchy," Journal of Personality and Social Psychology, 54: 638-646.

Howe, N. and Strauss, W. (2000). Millennials Rising: The Next Great Generation. NY: Vintage Books.

Kahle, L.R. (1983). Social Values and Social Change: Adaptation to Life in America. NY: Praeger Publishers.

Kerslake, P. (2005). "Words from the Ys," New Zealand Management, 52(4): 44-46. 
Khalek, A.M. (2007). "Religiosity, Happiness, Health, and Psychopathology in a Probability Sample of Muslim Adolescents," Mental Health, Religion and Culture, 10: 6.

Krahn, J.H. and Galambos, N.L. (2014). "Work Values and Beliefs of Generation X' and Generation Y,” Journal of Youth Studies, 17: 92-112.

Krejcie, R.V. and Morgan, D. (1970). "Determining Sample Sizes for Research Activities," Educational and Psychological Measurement, 30: 607-610.

Küçükusta, D., Mak, A., and Chan, X. (2013). "Corporate Social Responsibility Practices in Four and Five-Star Hotels: Perspectives from Hong Kong Visitors," International Journal of Hospitality Management, 34: 1930.

Lazarevic, V. (2012). "Encouraging Brand Loyalty in Fickle Generation Y Consumers," Young Lu, L., Rose, G.M., and Blodgett, J.G. (1999). "The Effects of Cultural Dimensions on Ethical Decision Making in Marketing: An Exploratory Study," Journal of Business Ethics, 18: 91. doi:10.1023/A:1006038012256.

McDaniel, S.W. and Burnett, J. (1990). "Consumer Religiosity and Retail Store Evaluative Criteria, Journal of the Academy of Marketing Science, 18: 101-112.

Meister, J. (2012). “Three Reasons You Need to Adopt a Millennial Mindset Regardless of Your Age." Retrieved from Forbes.com

Mokhlis, S. (2009). "Relevancy and Measurement of Religiosity in Consumer Behavior Research," International Business Research, 2(3): 75-95.

Morton, L.P. (2002). “Targeting Generation Y,” Public Relations Quarterly, 47(2): 46-48.

Noble, S.M., Haytko, D.L., and Phillips, J. (2009). "What Drives College-age Generation Y Consumers?" Journal of Business Research, 62(6): 617-628.

Posner, B.Z. and Schmidt, W.H. (1993). "Values Congruence and Differences between the Interplay of Personal and Organizational Value Systems," Journal of Business Ethics, 12(5): 341-347

Ralston, D.A., Egri, C.P., Reynaud, E., Srinivasan, N., Furrer, O., et al. (2011). "A Twenty-first Century Assessment of Values across the Global Workforce," Journal of Business Ethics, 104(1): 1-31.

Ramasamy, B., Yeung, M.C.H., and Au, A.K.M. (2010). "Consumer Support for Corporate Social Responsibility (CSR): The Role of Religion and Values," Journal of Business Ethics, 91: 61. doi:10.1007/ s10551-010-0568-0.

Rintamäki, T., Kuusela, H., and Mitronen, L. (2007). "Identifying Competitive Customer Value Propositions in Retailing," Managing Service Quality, 17(6): 621-634.

Roccas, S. and Schwartz, S.H. (1997). "Church-state Relations and the Associations of Religiosity with Values: A Study of Catholics in Six Countries," Cross-Cultural Research, 31: 356-375.

Rokeach, M. (1969) “The Role of Values in Public Opinion Research,” Public Opinion Quarterly, 32(4): 547-560.

Rokeach, M. (1973). The Nature of Human Values. NY: The Free Press.

Saroglou, V., Delpierre, V., and Dernelle, R. (2004). "Values and Religiosity: A Meta-analysis of Studies using Schwartz's Model," Personality and Individual Differences, 37: 721-734.

Schiffman, L.G. and Kanuk, L.L. (2010). Consumer Behavior (7 $7^{\text {th }}$ ed.). Englewood Cliffs, NJ: Prentice Hall.

Schwartz, S.H. (1992). "Universals in the Content and Structure of Values: Theory and Empirical Tests in 20 Countries," in M. Zanna (ed.). Advances in Experimental Social Psychology 25: 1-65. http://dx.doi.org/10.1016/S0065-2601(08)60281-6 
(1994). "Are there Universal Aspects in the Content and Structure of Values?" Journal of Social Issues, 50: 19-45.

-----, (2001). "The Nature of the Relationship between Corporate Codes of Ethics and Behavior," Journal of Business Ethics, 32(3): 247-262.

, (2005). "Basic Human Values: Their Content and Structure Across Countries," in A.

Tamayo and J.B. Porto (Eds.), Valores e Comportamento nas Norganizações (Values and Behavior in Organizations): 21-55. Petrópolis, Brazil: Vozes.

Schwartz, S.H. and Bilsky, W. (1987). "Toward a universal psychological structure of human values," Journal of Personality and Social Psychology 53: 550-562.

Schwartz, S.H. and Huismans, S. (1995). "Value Priorities and Religiosity in Four Western Religions," Social Psychology Quarterly, 58: 88-107.

Schwartz, S.H. and Rubel, T. (2005). "Sex Differences in Value Priorities: Cross-cultural and Multimethod Studies," Journal of Personality and Social Psychology, 89(6): 1010-1028. doi: http://dx.doi. org/10.1037/0022-3514.89.6.1010.

Schwartz, S.H. and Sagiv, L. (1995). "Identifying Culture-specifics in the Content and Structure of Values," Journal of Cross-Cultural Psychology, 26: 92-116.

Seligman, C. and Katz, A.N. (1996). "The Dynamics of Value Systems," in Clive Seligman, J.M. Olson and M.P. Zanna (eds.), The Psychology of Values. The Ontario Symposium, Volume 8. NJ: Mahwah, Lawrence Erlbaum Associates.

Shafer, W.E., Fukukawa, K., and Lee, G.M. (2007). "Values and the Perceived Importance of Ethics and Social Responsibility: The U.S. versus China." Journal of Business Ethics, 70: 265. doi:10.1007/ s10551-006-9110-9.

Shaw, D., Grehan, E., Shiu, E., Hassan, L., and Thomson, J. (2005). "An Exploration of Values in Ethical Consumer Decision Making,” Journal of Consumer Behaviour, 4(3).185-200.

Shukor, A. and Jamal, A. (2013). "Developing Scales for Measuring Religiosity in the Context of Consumer Research," Middle-East Journal of Scientific Research, 69-74.

Sözer, B.E. (2014), August 29. "Y Kuşağı Ne Ister? (What Gen Y want?).” Hürriyet. Retrieved from http://www.hurriyet.com.tr.

Spini, D. (2003). "Measurement Equivalence of 10 Value Types from the Schwartz Survey Across 21 Countries," Journal of Cross Cultural Psychology, 34: 3-23. Turkish Presidency of Religious Affairs, July 2015, retrieved from http:diyanet.gov.tr

Tabachnick, B.G. and Fidell, L.S. (1996). Using Multivariate Statistics (3 ${ }^{\text {rd }}$ ed.). NY: HarperCollins.

Tulgan, B. and Martin, C.A. (2001). Managing Generation Y: Global Citizens Born in the Late Seventies and Early Eighties. Amherst, Massachusetts: HRD Press.

------, (2006). Managing the Generation Mix ( $2^{\text {nd }}$ ed.), Amherst, Massachusetts: HRD Press.

Vitell, S.J. and Paolillo, J.G.P (2013). "Consumer Ethics: The Role of Religiosity," Journal of Business Ethics, 46: 151-162

Wilkes, R.E., Burnett, J.J., and Howell, R.D. (1986). "On the Meaning and Measurement of Religiosity in Consumer Research," Journal of the Academy of Marketing Science, 14: 47-56.

Wolburg J. and Pokrywczynski J. (2011). "A Psychographic Analysis of Generation Y, College Students," Journal of Advertising Research, 41: 33-53.

Wulff, D.M. (1991). Psychology of Religion: Classic and Contemporary Views. NY: Wiley. 